\title{
The Characteristics of Assessment Instrument Model In Learning Indonesian Language
}

\author{
Endang Siwi Ekoati ${ }^{1}$, Fathur Rakhman ${ }^{2}$, Ida Zulaeha ${ }^{3}$, Subyantoro ${ }^{4}$ \\ \{Ekoati5131@gmail.com ${ }^{1}$ \} \\ 1,2,3,4Pendidikan Bahasa Indonesia Universitas Negeri Semarang, Indonesia
}

\begin{abstract}
Assessment problems are still a major problem in the implementation of the 2013 curriculum even though they have been implemented for years. Based on several studies it is known that most teachers cannot design, develop instruments, implement, manage, report, utilize the results properly. The main difficulties experienced by teachers are formulating indicators, organizing instrument items, and making assessment instruments. Thus it is deemed necessary to develop an easy and applicable assessment instrument to help teachers make authentic assessments in learning Indonesian. The first step that must be done is to analyze the needs of teacher and student teachers. Preliminary surveys show that teachers and students need transparent and accountable assessment instrument models. The model can be used as a teacher's reference in conducting assessments. This model is expected to improve the competence of the 21 st century: to think critically and solve problems, collaborate and communicate, and to enhance creativity. The characteristics of the model are concluded from the needs analysis carried out through survey, interview, and observation.
\end{abstract}

Keywords: the characteristics, assessment instrument model, Indonesian language

\section{INTRODUCTION}

Learning assessment in 2013 curriculum must cover affective, cognition, and skill. However, based on monitoring and evaluation results of 2013 curriculum implementation on JHS level in 2014, it showed that teachers still had difficulties in conducting the assessment. About $60 \%$ teacher respondents stated they were incapable to design, implement, process, report, and use the assessment results properly. The main difficulties faced by them were: (1) formulating indicators, (2) arranging points of instrument, (3) implementing affective assessment by using various techniques, (4) being less believing in implementing skill assessment, (5) being incapable to understand the way of arranging both skill assessment rubric and instruments, (6) being incapable to formulate points of questions dealing with factual, conceptual, procedural, and metacognitive knowledge which would be combined by low-high order thinking skills (Kemdikbud, 2017:1-2).

Assessment is often merely considered as methods to measure learning achievement. Thus, it is considered being separated from learning. This assumption causes many teachers to allocate their assessing time separately. It should not only be used to know the learning achievement but also to improve learning process. Assessment can be used to improve students' abilities in learning process (Shepard, 2000). 
Assessment can be done in three approaches: assessment of learning, assessment for learning, and assessment as learning. Assessment of learning is an assessment done after learning session. This assessment is usually done by teachers after teaching at least one basic competence. The assessment is done after all materials have been taught although the basic competence may be complex and need longer meeting times. The examples are midterm test, final semester test, and school test (Schuwirth, Lambert W. T \& Cees P. M. Van Der Vluten:2011).

Assessment for learning is done within learning process and used to improve learning process. It allows teachers to provide feedback to learning process, to monitor the development of the students, and to determine the students' improvements. Assessment for learning allows teachers to improve the students' performance through various activities, such as presentation, task, and project (Chappuis and Richard J. Stiggins, 2002; Sally, 2005; Taras, 2009; MacLellan, 2010; Wiliam, 2011; Chianese, 2012). The use of portfolio assessment and the use of scoring rubrics for performance assessments are both considered best practices in classroom assessment, of course, but they do not necessarily reflect the real-world evaluation of real-world tasks (Frey, 2012).

Assessment as learning is equally defined as assessment for learning. However, the difference deals with students' involvements during assessing process. The students are given selfassessment experience for themselves and to assess their peers. They are also involved in formulating procedures, criteria, rubrics, and guidance of assessment. It is done to ensure them knowing what they should do to gain optimal learning ways. Assessment that can be used as a part of instruction to support and enhance learning. Learning-by-doing is generally considered the most effective way to learn. Although foundational skills (reading, writing, mathematics, history, language) remain essential, a more complex set of competencies are required today (Shepard, 2000; Lombardi, 2007).

Authentic assessment in the curriculum implementation is expected to be capable of measuring affective, cognitive, and skill aspect. Those aspects need to have proper proportion and conducted appropriately to allow students growing not only as brilliant people but also skillful and intellectual people with good characteristics. It is in line with learning purpose which is not only to get knowledge and certain skill but to develop positive attitudes. Authentic assessment is naturalist method to gain functional and contextual informasion dealing with daily learning (Kelty et al., 2009). It is in line with the opinion Yastibas (2015), emphasizes learning by doing, as the main focus is on learning by doing, assessing this processrequires different assessment methods that take factors, such as students' understanding and personal difference into consideration, while evaluating learners' performance. This should take various techniques which are capable of measuring students' competences accurately. The use of certain techniques will influence to the numbers of used instruments. On its assessing instruments, besides scoring, there should be observation, check list, assessment scale, and rubric which used plural criteria - at least two criteria (Chatib, 2015:140).

Assessment is authentic when we directly examine student performance on worthy intellectual tasks. It is a task realization demanding students to show their real actual performance meaningfully in implementing knowledge and skill (Wiggins, 1990; Mueler, 2008; Nurgiyantoro, 2016). Therefore, authentic assessment is not merely measurement of learning achievement but also actual performance during learning process.

Authentic assessment allows teachers to measure directly the actual performance of students. For teachers, assessment is an activity to see strength and weakness points of students and to 
evaluate actual performance of the teacher. Therefore, teacher should implement assessment daily with systematic and well-planned schedule. It can be done when teachers plan carefully and implement it accurately to the tested materials.

On teaching and learning activities, teacher can assess actual performance by asking students to demonstrate certain behavior or skill which then will be assessed authentically. Authentic assessment brings demonstration one step ahead and emphasizes the importance of skill implementation or actual-real world context skill. Nurgiyantoro (2011:23) stated that authentic assessment emphasized learners to demonstrate their owned knowledge in real and meaningfully.

Lund (1997) stated eight characteristics of authentic assessment: (1) orienting to learning objectives, (2) employing meaningful task, (3) developing high thinking order skill, (4) assessing based on already known criteria by students, (5) having clear instruction, (6) providing chance for students to demonstrate their competences, (7) respecting achievement of students' actual performance, and (8) assessing process and product. Such guidelines enable teachers to create learning environments using authentic contexts and scenarios that ensure assessment truly measures whether students can use their knowledge effectively and realistically, as opposed to the reproduction of surface knowledge that is quickly forgotten after an examination or test (Herrington, J. \& Herrington, A., 2006). Those characteristics will be used as reference to develop authentic assessment instruments in 2013 curriculum - Indonesian language learning Besides that, other steps to develop authentic assessment instrument model are based on main steps of authentic instrument development by Sani (2016:34); Denisa et al (2016): (1) having standard, (2) developing authentic task, (3) determining criteria, and (4) developing rubric. The product in the form of authentic assessment instruments of Indonesian language lesson will be developed by using Borg and Gall research development model (2007:589-593).

\section{METHODOLOGY}

This Borg and Gall Research Development model (1983:775-776) consisting of: (a) research and information collection, (b) plan, (c) preliminary product form development, (d) preliminary field test, (e) main product revision, (f) main field test, (g) operational product revision, (h) operational field test, (i) operational product revision, (j) operational field test, (k) final product revision, and (1) dissemination and implementation.

Based on the notion, the steps according to current research's needs were formulated. The steps were packaged into several steps: (1) preliminary survey, (2) initial product design development, (3) product design, (4) product validity test, (5) revision of developed product design of validity test result, (6) limited trial run, (7) final design revision, and (8) massive train run of the developed product, (9) final product, and (1) dissemination and implementation. This research was conducted until the eighth step. Those eight steps are shown on the flow of authentic instrument development model stages of 2013 curriculum Indonesian language lesson: 


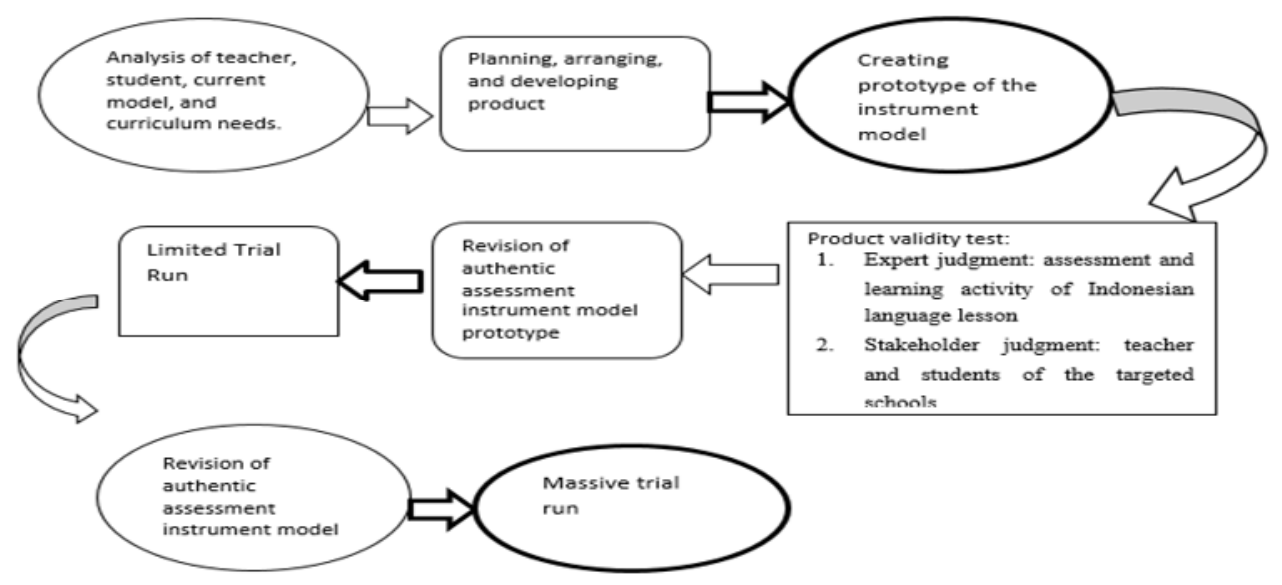

Figure 1. The Steps of Authentic Assessment Instrument Development in Learning Indonesian Language

Based on Borg and Gall research and development model, the first step is preliminary survey. It demanded researchers to analyze teacher, students', current curriculum, and literature study needs. The preliminary survey was divided into two: dealing with teacher's needs and students" needs. The instrument for teacher consisted of ten questions with different choice of answers depending on the investigated content. Teacher could select more than one answer. The students, in another hand, were given eight question to investigate deeper their needs of authentic assessment. They could select more than one answers of each question.

To get data of authentic instrument model needs quickly, the instruments were created by Google form application. This instrument in the form of application was given to both teacher and students of JHS/SHS in Central Java. Based on the monitoring for one year and five days, there were 28 teachers whom had contributed to fill in. They were from Kudus, Pati, Surakarta, Purbalingga, and Wonogiri. Meanwhile, the instrument of the students' needs was filled by 264 students of JHS/SHS from Kudus, Surakarta, and Wonogiri Central of Java. Based on the results, the data was formulated and analyzed in term of their needs of authentic assessment instrument model in learning Indonesian language.

\section{FINDINGS AND DISCUSSION}

The findings were described based on first development stage - preliminary survey. The analysis of needs of this research was activity to collect information dealing with factual condition and ideal instruments. The analysis was done by concluding the questionnaire and respondents' suggestions.

Based on the first question of student questionnaire, it was known that 255 out of 264 respondents (97\%) assumed assessment was important matter in learning. It showed that most of 
the students agreed that assessment becoming unseparated part of teaching-learning. The answer of the first question is strengthened by the second answer telling that teacher needs to conduct assessment in class. As many as 247 students (94\%) answered that teacher needed to conduct assessment to measure his mastered abilities.

Besides students, teachers also assumed that assessment was important factor in learning. However, problem of assessment always becomes main problem in conducting learning. There are still many teacher having less understanding to conduct authentic assessment. Based on 28 questionnaires, 8 teachers (29\%) answered they had not known how to conduct authentic assessment. Dealing with second question, whether teacher needed authentic assessment instruments, all teachers (100\%) answered they needed it.

The students and teachers' answers of the first two questions were used as basic to arrange plan and develop product. Then, there would be a need to conduct analysis of characteristics of development needs based on teachers' and students' perceptions. Here are the characteristics of the assessment model need in learning Indonesian language.

\subsection{Development Needs based on Teachers' Perceptions}

The need analysis of the instrument model covered four aspects: (1) need of authentic assessment instrument model form, (2) content, (3) presentation, and graphs. Here are the explanation of the aspects.

\section{1) Needs of Authentic Assessment Instrument Model Forms}

On the third instrument, it was questioned the forms of the instrument model by options (1) book, (2) web, and (3) others. The answers could be seen below in graphic 1.

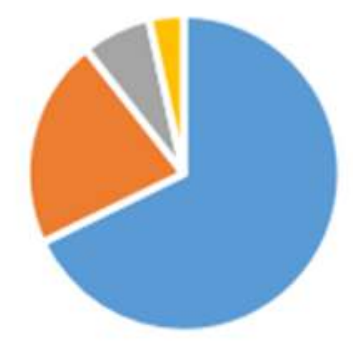

" Book $=$ Book/Web $=$ Web $=$ Others

Graphic 1. Needs of Assessment Instrument Model Forms

Based on the graphic, it can be described that 19 out of 28 teachers (86\%) chose books, 6 (21\%) chose book and web, 2 (7\%) chose web, and 1 (4\%) chose other forms without any reason. It proved that most of the teachers demanded the model in the form of books. 


\section{2) Needs of Content/Book Content}

The needs of content/book content of authentic assessment instrument were based on questions $4,5,6,7$, and 8 of the questionnaire. It could be concluded that (1) the form of the demanded instrument model covered affective, cognitive, and skill aspects; (20 there was a need of explaining steps to assess affective, cognitive, and skill competences structurally and completely; (3) there was a need of the instrument model assessment dealing with affective, cognitive, and skill competences.

\section{3) Needs of Presentation and Language}

Based on question number 9 about presentation and language, most of teachers demanded the presentation of book would be packaged with communicative and systematic language. Therefore, to avoid any ambiguity for the readers, then the selected style presentation of the book was scientific language variety.

\section{4) Needs of Graphics}

Based on question 10, the answer was not like the previous answers. Most of the teachers did not answer exactly. Question 10.1 dealing with book title, only 11 respondents (39\%) giving suggestion dealing with the title. The other 16 respondents (57\%) let the answer blank. There was only 1 teacher (3.5\%) suggesting the title to be made attractive.

Question 10.2 about color of the paper, 14 respondents (50\%) chose white, 5 respondents (18\%) chose book paper, 9 respondents (32\%) did not suggest anything. The similar thing went on paper size, book size, cover picture, book design, cover color, and fonts. There were many of the teachers uncertainly answered.

The general suggestion by respondents were: (1) to immediately realize the book, (2) to supplement the book with examples, (3) to make it easier and practical, (4) to make it more creative and better, and (5) to supplement it by illustration of each domain - affective, cognitive, and skill.

\subsection{Needs of Development based on the Students' Perceptions}

The survey results were based on number 3 question about when the assessment should be conducted. The answers were: (1) 124 respondents selecting during learning process (47\%), (2) 70 respondents $(26.5 \%)$ selecting to have specific time, (3) 66 respondents $(25 \%)$ selecting to be at home, and (4) 4 respondents (1.5\%) providing no answers. The answers of the students can be seen on graphic 2 . 


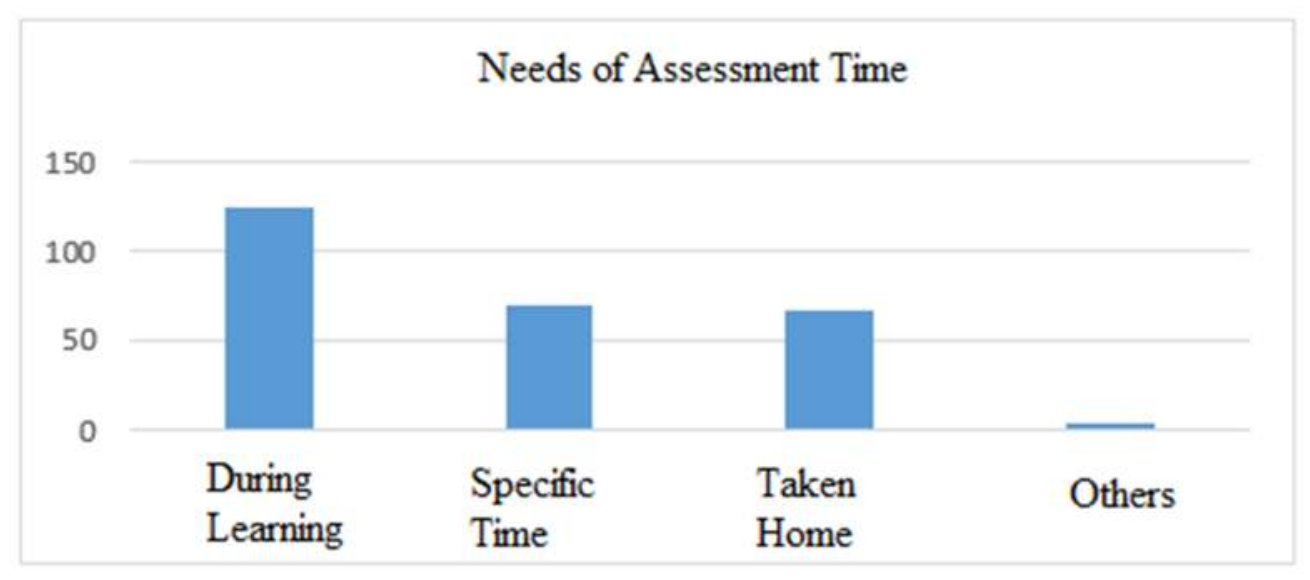

Graphic 2. Needs of Assessment Time

From the survey dealing with needs of assessment time, most of the students chose to be conducted during learning. $26.5 \%$ of the students chose to have specific time while the others preferred to take it home. Therefore, the assessment should be better to be conducted within learning process with assessment for learning and assessment as learning principles on each ending of Core Competence. Thus, it could improve learning process. It is in line with authentic assessment principle which allows teachers to measure directly the students' actual performances.

The findings were strengthened by answers of questions number 4 and 5 about affective assessment model, number 6 and 7 about cognitive assessment, and number 8 about skill assessment. Generally, the students chose various, meaningful, and student-oriented assessment model.

\section{CONCLUSION}

Based on the analysis of teachers and students' needs, it can be concluded that characteristics of authentic assessment instrument model needs in learning Indonesian language were: (1) realized into book, (2) covering affective, cognitive, and skill aspect of assessment instruments, (3) allowing to measure actual performances of students during learning both inside and outside of class, (4) realizing into various assessment forms, (5) using communicative and systematic language, and (6) packaging the graphic of the assessment instrument model book attractively.

The characteristic analysis of authentic assessment instrument model needs in learning Indonesian language would be used as basic to plan and arrange product development stage. Then, it would be continued by making prototype of the model for 2013 curriculum Indonesian language lesson. 


\section{REFERENCE}

Borg, Water R., Maredith D. Gall and Joyce P. Gall. 2007. Educational Research. New York: Longman.

Chatib, Munif. 2015. Sekolahnya Manusia: Sekolah Berbasis Multiple Intelligences di Indonesia. Bandung: Kaifa.

Denisa, Kral'ovicova. Authentic Assesment in Context of ESP. International Saintific and Practical Conference "World Science” . ISSN 2413-1032. No. 3(7) Vol 4 March 2016. Google Scholar.

Frey, Bruce B., Vicki L. Schmitt, and MO Justin P. Allen. 2012. Defining Autentik Classroom Assessment. Practical Assessment, Research \& Evaluation. Volume 17, Number 2, ISSN 1531-7714. Google Scholar.

Chappuis, Stephen and Richard J. Stiggins. 2002. Classroom Assessment for Learning. Educational Leadership. September 2002. Volume 60. Number 1. Pages 40-43. Google Scholar.

Chianese, Gina. 2012. Assessment for Learning: a Way to Improve Continuously. Procedia Social and Behavioral Sciences 46 (2012) 2927-2931. Google Scholar.

Herrington, J. \& Herrington, A. (2006) Authentic conditions for authentic assessment: Aligning task and assessment, in Critical Visions, Proceedings of the 29th HERDSA Annual Conference, Western Australia, 10-12 July 2006: pp 146-151. Google Scholar.

Kemdikbud. 2017. Panduan Penilaian untuk Sekolah Menengah Pertama, Cetakan Ketiga. Jakarta: Direktorat Pembinaan SMP.

Keilty Bonnie, Diana J. LaRocco dan Faye Bankler Casell. 2009. "Early Interventionists' Reports of Authentic Assessment Methods Through Focus Group Research". Topics in Early Childhood Special Education. Hammill Institute on Disabilities. Google Scholar.

Lombardi, Marilyn M. Authentic Learning for the $21^{\text {st }}$ Century: An Overview. Educause Learning Initiative. Paper May 2007.

Lund, J. (1997). Authentic assessment: Its development \& applications. The Journal of Physical Education, Recreation \& Dance, 68(7), 25-40. Google Scholar.

MacLellan, Effie. 2010. Assessment for Learning: The Differing Perceptions of Tutors and Students. Assessment \& Evaluation in Higher Education. Volume 26, 2001 - Issue 4. Google Scholar.

Mueller, John. 2008. Authentic Assesment Toolbox. North Central College, Naperville. Http://jonathan.muller.faculty.noctrl.edu/toolbox/index.htm. Google Scholar.

Nurgiayantoro, Burhan. 2011. Penilaian Otentik dalam Pembelajaran Bahasa. Yogyakarta: Gadjah Mada University Press.

Nurgiyantoro, Burhan. 2016. Penilaian Pembelajaran Bahasa Berbasis Kompetensi. Yogyakarta: BPFE-Yogyakarta.

Sally, Brown. 2005. Assessment for Learning. Learning and Teaching in Gihger Education (1). Pp. 8189. ISSN 1742240X. Google Scholar.

Sani, Ridwan Abdullah. 2016. Penilaian Autentik. Jakarta: Bumi Aksara

Schuwirth, Lambert W. T \& Cees P. M. Van Der Vluten. Programmatic Assessment: From Assessment of Learning to assessment for Learning. Medical Teacher. 2011; 33: 478485. Google Scholar. 
Shepard, Lorrie a. 2000. The Role of Assesment in a Learning Culture. Educational Researcher. Vol, 29, No. 7. PP. 4-14. Google Scholar.

Taras, Maddalena. 2010. Assesment for Learning: Assessing the Theory and Evidence. Procedia Social and Behavioral Sciences 2 (2010) 3015-302. Google Scholar.

Wiggins, Grant. The Case for Authentic Assessment. Practical Assessment, Research \& Evaluation. Volume 2, Number 2, November, 1990 ISSN=1531-7714. Google Scholar.

Wiliam, Dylan. 2011. What is Assesment For Learning? Studies in Educational Evaluation. 37 (2011). Google Scholar.

Yastibas, Ahmet Erdost and Gulsah Cinar Yastibas. 2015. The Use of e-Portofolio Based Assessment to Develop Students Selfregulated Learning in English Language. Procedia Social and Behavioral Sciences 176 ( 2015 ) 3 - 13. Google Scholar. 